\title{
Secretion of urokinase and plasminogen activator inhibitor-1 by normal colonic epithelium in vitro
}

\author{
P Gibson, O Rosella, G Rosella, G Young
}

\begin{abstract}
Urokinase is a neutral protease whose major site of action is the external surface of the plasma membrane of cells and whose major function seems to be modulation of cell adhesion, such as that which occurs during cell migration. This study aimed to determine whether colonic epithelium is involved with the urokinase system. The contents of urokinase and one of its specific inhibitors, plasminogen activator inhibitor-1, were measured in culture supernatant and cell homogenates of isolated human colonic crypt cells. The amounts of both factors increased in supernatants over 24 hours, and approximately twice the amount was found in supernatants than in autologous cell homogenates. The secretion of both factors was similar in serum free and serum containing media. Northern blot analysis showed that messenger ribonucleic acid specific for urokinase and plasminogen activator inhibitor-1 was present in colonic crypt cells and that expression over 18 hours of culture was increased 12 fold for urokinase type plasminogen activator and two to fourfold for the inhibitor compared with values found in autologous freshly isolated cells. Urokinase activity was detected in crypt cell homogenates and supernatants indicating that it was present in excess of its inhibitors. Control experiments indicated that the epithelial cells themselves were responsible for the observations and excluded artefactual effects of the isolation procedure. In conclusion, isolated human colonic epithelial cells secrete urokinase and at least one of its specific inhibitors. Further investigation of the role of urokinase in the physiology and pathophysiology of colonic epithelium is indicated.
\end{abstract}

(Gut 1994; 35: 969-975)

Department of Medicine, University of Melbourne, The Royal Melbourne Hospital, Victoria, Australia

P Gibson

O Rosella

G Rosella

G Young

Correspondence to: Dr P R Gibson, Department of Medicine, The Royal Melbourne Hospital, Victoria 3050, Australia.

Accepted for publication 28 October 1993
Urokinase type plasminogen activator (u-PA) is a neutral protease whose major physiological substrate seems to be plasminogen, from which is generated plasmin, itself a neutral protease. The wide range of substrates for plasmin includes major constituents of basement membrane, such as laminin, fibronectin, and proteoglycans. u-PA also digests fibronectin directly. ${ }^{1}$ Current evidence indicates that the major site of action of u-PA in vivo is bound to specific receptors on the external surface of the plasma membrane. ${ }^{24}$ Receptors for u-PA (u-PAR) have been found on most cell types examined (except some circulating cells and occasional cell lines). ${ }^{5}$ Most cells bearing u-PAR have also been found to secrete u-PA. ${ }^{5}$

Current knowledge of the relationship between the u-PA system and colonic epithelium is rudimentary. u-PA is present in mucosal homogenates and its content and activity increase in the presence of mucosal inflammation. ${ }^{67}$ Freshly isolated colonic crypts have cell associated u-PA activity and, in subcellular fractionation experiments, this co-localised with markers of the plasma membrane ${ }^{8}$ suggesting that colonic epithelial cells express u-PA receptors on their plasma membrane. In situ hybridisation experiments using human colonic mucosa from patients with large bowel cancer have demonstrated the expression of messenger ribonucleic acid (mRNA) for u-PA receptors in a very small proportion of colonic epithelial cells. ${ }^{9}$ It has not been established, however, whether the u-PA activity found associated with colonic epithelial cells derived from the epithelial cells themselves or from other cells. In situ experiments have found little evidence of mRNA for u-PA in normal colonic epithelium in humans or mice. ${ }^{910}$ The only evidence that colonic epithelial cells may be capable of secreting u-PA comes from studies of colon cancer cells lines which secrete u-PA and also express u-PA receptors. ${ }^{3} 11$

The net activity of $\mathrm{u}-\mathrm{PA}$ at the cell surface is also dependent upon local concentrations of the fast acting specific inhibitors of u-PA, plasminogen activator inhibitors 1 and 2 (PAI-1, PAI-2) ${ }^{12}{ }^{13}$ as well as other, less specific inhibitors such as PAI- $3^{14}$ and protease nexins. ${ }^{15}$ PAI-1 seems to be secreted by a variety of cells, including epithelial cells, while PAI-2 production appears to be more restricted, especially to monocytes and macrophages. ${ }^{12} 13$ Whether colonic epithelium secretes these inhibitors is not known. Because of the potential importance of u-PA to the physiology and pathophysiology of the colonic epithelium, this study aimed to determine whether colonic crypt cells isolated from macroscopically normal human large bowel can produce and secrete u-PA or PAI-1, or both, in vitro.

\section{Methods}

\section{ISOLATION OF COLONIC CRYPTS}

Macroscopically normal mucosa was obtained from surgically resected large bowel. Surgery was performed on 10 patients because of nonmalignant large bowel disease. Five of these patients had diverticular disease, one with presumed colonic bleeding (histologically 
normal); three had recurrent sigmoid volvulus; and one patient with a normal large bowel was misdiagnosed as having a caecal carcinoma by barium enema. The tissue from these patients was considered to represent normal large bowel mucosa. Tissue was obtained from the proximal colon in two and the distal colon in eight patients. The ages of these patients ranged from 62 to 83 (mean 73) years and three were men. In 10 patients, the large bowel was resected because of colorectal carcinoma. These patients were aged from 59 to 81 (mean 70) years and four were men. Tissue was taken more than $10 \mathrm{~cm}$ from the edge of the tumour and adjacent mucosa was histologically normal. Two specimens were from the proximal colon, three from the distal colon, and five from the rectum. The procurement of colonic specimens was approved by The Royal Melbourne Hospital Board of Medical Research and Ethics Committee.

Colonic crypt cells were isolated from resected mucosa using the collagenase/Dispase technique as previously described. ${ }^{16}$ Cell populations were contaminated with less than $8 \%$ non-epithelial cells on morphological criteria and the viability of colonic epithelial cells immediately after isolation was always $>98 \%$ as assessed by $0 \cdot 1 \%$ trypan blue exclusion. The culture media in which the viability of crypt cell populations have been studied in detail previously comprised either Dulbecco's modification of Eagle's medium containing $20 \%$ Nu-serum (Collaborative Research, Bedford, Mass, USA), $25 \mathrm{mmol} / 1$ HEPES, 4 $\mathrm{mmol} / 1 \mathrm{~L}$-glutamine, $50 \mathrm{U} / \mathrm{ml}$ penicillin, 50 $\mu \mathrm{g} / \mathrm{ml}$ gentamicin, and $100 \mathrm{U} / \mathrm{ml}$ nystatin ${ }^{16-18}$ or the same medium but without addition of Nu-serum. ${ }^{18}$ Criteria upon the continuing viability of crypt cell populations over 16-24 hours in culture has been established, including ultrastructure, ${ }^{16}$ rates of protein and DNA synthesis, ${ }^{16-18}$ and leakage of intracellular proteins from ${ }^{51} \mathrm{Cr}$-prelabelled cells. ${ }^{16} 18$

\section{ASSAYS OF UROKINASE AND PAI-1}

Colonic crypt cells were cultured in 96 U-bottomed well plates, harvested by aspiration, and centrifuged at $300 \mathrm{~g}$ for five minutes to allow separation of the supernatant and the cells. The cell pellet was then washed in phosphate buffered saline, mechanically homogenised in $1 \mathrm{ml}$ of mannitol buffer (50 $\mathrm{mmol} / \mathrm{l} \mathrm{D}$-mannitol and $2 \mathrm{mmol} / \mathrm{l}$ trizma base in $\mathrm{dH}_{2} \mathrm{O}, \mathrm{pH} 7 \cdot 4$ ), and Triton-X 100 was added to a final concentration of $0 \cdot 1 \%$. Both the cell homogenates and supernatants were stored at $-20^{\circ} \mathrm{C}$ until assayed. All studies were performed in triplicate or quadruplicate. The u-PA content and activity and PAI-1 content were measured in the supernatants and cell homogenates and, where appropriate, the results were expressed relative to the cell protein content, measured using bovine gamma globulin as standard. ${ }^{19}$

The urokinase content was measured in all supernatants and cell homogenates by ELISA (\#844 Imubind-5 u-PA ELISA kit, American Diagnostica Inc, New York, NY) as previously described. ${ }^{20}$ This assay measures free u-PA and inhibitor bound $\mathrm{u}-\mathrm{PA}$, the latter with an efficiency of $>80 \%$, but its ability to measure receptor bound u-PA, while inferred, has not been reported. $u-P A$ activity was measured in serum free supernatants and all cell homogenates by the colorimetric method of Coleman and Green, ${ }^{21}$ as previously described. ${ }^{8}$ Because of the presence of plasminogen in the assay, the activities of both pro-u-PA and u-PA are measured. The results were corrected for the presence of plasminogen independent proteinases (which were usually not detectable). PAI-1 was measured by ELISA (\#822/1 Imubind PAI-1 ELISA kit, American Diagnostica Inc, New York, NY) which measures both free and u-PA bound PAI-1, the latter with $80 \%$ efficiency. ${ }^{22}$ The coefficient of variation between replicate wells for all assays was $<10 \%$.

\section{NORTHERN BLOT ANALYSIS}

Total RNA was extracted from both freshly isolated and cultured colonic crypt cell populations using the guanidium thiocyanate method. ${ }^{23}$ Total RNA $(10 \mu \mathrm{g})$ was denatured with formamide and separated on $1.4 \%$ agarose-formaldehyde $(2 \cdot 2 \mathrm{~mol} / \mathrm{l})$ gels. Ethidium bromide staining of the gel was used to assess the integrity and to monitor the loading of the RNA. After overnight (18 hour) transfer of the RNA to a nylon membrane (Zeta-Probe, BioRad, Richmond, CA), hybridisations were performed using a $1.2 \mathrm{~kb}$ human $\mathrm{u}-\mathrm{PA} \mathrm{cDNA}$ probe, ${ }^{24}$ labelled with ${ }^{32} \mathrm{P}$-dATP (specific

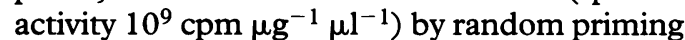
(Promega Corporation). All autoradiograms were exposed using two intensifying screens for four days at $-70^{\circ} \mathrm{C}$. Membranes were stripped by heating in a buffer containing $15 \mu \mathrm{mol} / 1$ sodium chloride, $1.5 \mu \mathrm{mol} / 1$ trisodium citrate and $0.5 \%$ sodium dodecyl sulphate for 40 minutes at $95^{\circ} \mathrm{C}$ before reprobing with a $3 \mathrm{~kb}$ PAI-1 cDNA, ${ }^{25}$ also random primed with ${ }^{32}$ dATP. A glyceraldehyde phosphate dehydrogenase (GAPDH) cDNA was used as a housekeeping' gene to correct for uneven RNA loading on gels. Where indicated, laser densitometry (LKB 2202 Laser Densitometer, LKB Products, Sweden) was used to normalise the intensity of the specific mRNA bands relative to GAPDH. The linear range of $x$ ray exposure was used in all experiments.

\section{CONTROL EXPERIMENTS}

\section{Effects of the isolation process}

The potential effect of the isolation process on the production of u-PA by colonic epithelial cells was assessed in the colon cancer cell line, LIM1863, the gift of $R$ Whitehead, Ludwig Institute for Cancer Research, Melbourne. These cells grow in suspension in crypt like structures ${ }^{26}$ and can be handled similarly to normal crypts. They were harvested by mild mechanical trauma and sieved through a fine stainless steel mesh to remove large cell lumps before study. The cells were incubated for 90 
minutes in medium containing collagenase and Dispase identical to that used in the isolation process, and were then processed as for colonic crypts. A control population was treated similarly but without the enzymes in the medium. The production of $\mathrm{u}-\mathrm{PA}$ and PAI-1 by the cells was then measured and compared.

Effects of contaminating non-epithelial cells The non-epithelial cells that contaminate colonic crypt populations have previously been characterised and mostly comprise mononuclear and plasma cells with some mesenchymal (vimentin positive) cells. ${ }^{16}$ These cells were isolated from resected mucosa firstly by removing the colonic epithelium by incubation for 90 minutes in multiple changes of Hank's buffered saline solution containing $3 \mathrm{mmol} / \mathrm{EDTA}$, followed by vigorous shaking. The epithelia depleted mucosa was scraped from the submucosa and subjected to collagenase/Dispase digestion, trituration, sieving, and washing
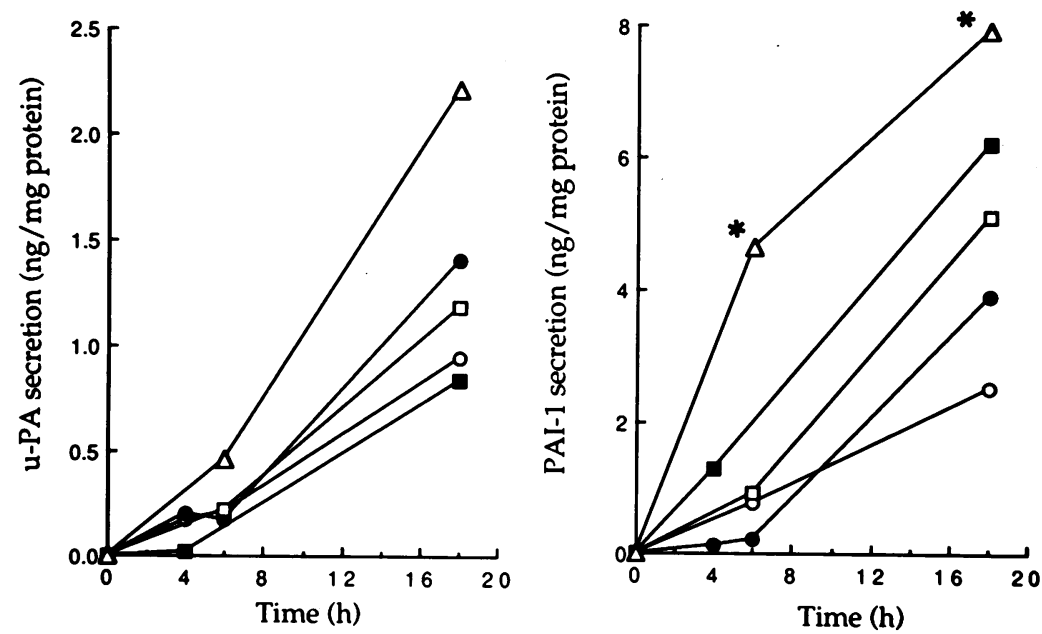

Figure 1: The content of urokinase type plasminogen activator $(u-P A)$ and plasminogen activator inhibitor-1 (PAI-1) in supernatants of colonic crypt cells at various time points during the 18 hours' culture. The symbols correspond to results from the same cell population in each graph. The asterisks indicate values that have been reduced by $80 \%$ for ease of graphic presentation.
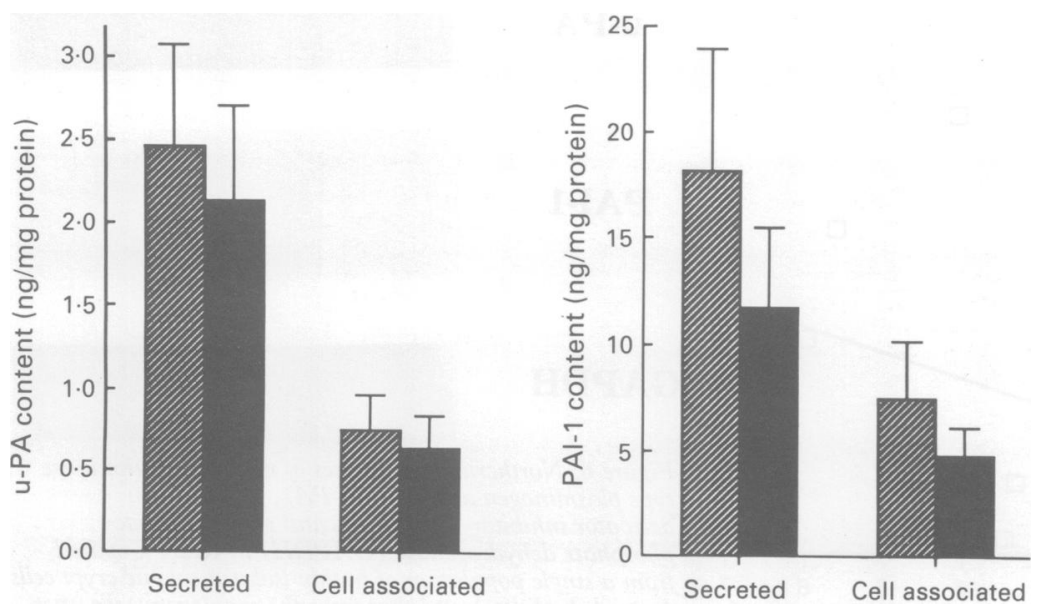

Figure 2: The content of urokinase type plasminogen activator ( $u-P A)$ (left) and plasminogen activator inhibitor-1 (PAI-1)(right) in autologous supernatants and cell homogenates of colonic crypt cells isolated from normal (hatched) or cancer bearing colons (shaded) after 24 hours'culture (shown as mean (SEM)). Significantly less $u-P A$ $(p<0.001)$, paired $t$ test $)$ and less PAI-1 $(p=0.013)$ were found in cell homogenates compared with autologous supernatants. Disease related differences in $u-P A$ or $P A I-1$ content were not statistically different. steps as for colonic epithelial cells except that centrifugation was performed at $300 \mathrm{~g}$ for five minutes. The resulting population, which was shown to be contaminated with $<10 \%$ epithelial cells on light microscopy, was then cultured and harvested in the same way as for colonic crypt cells and the u-PA and PAI-1 content of both cell homogenates and supernatants was measured.

\section{STATISTICAL EVALUATION}

Relevant data are expressed as mean (SEM). Paired/unpaired data have been compared using Wilcoxon rank sign/sum tests, or the paired Student's $t$ test respectively according the number of replicate experiments performed and the distribution of the data. Differences across large bowel regions were assessed by the Kruskall-Wallis test. u-PA activities were compared by linear regression analysis with the content of u-PA and PAI-1 and the ratio between them. The Pearson correlation coefficient ( $r$ ) was calculated. Differences with a $p$ value $\leqslant 0.05$ were considered to be statistically significant.

\section{Results}

SECRETION OF U-PA BY COLONIC CRYPT POPULATIONS

There was a time dependent increase in the concentration of u-PA in supernatants of cultured colonic crypt cells, and, as shown in Figure 1, the appearance of u-PA seemed to accelerate between 12 and 18 hours compared with the $0-6$ hours period. The cell associated u-PA content also increased over the culture period from $0.11(0.03) \mathrm{ng} / \mathrm{mg}$ protein in freshly isolated cells to $0.57(0 \cdot 13) \mathrm{ng} / \mathrm{mg}$ at 18 hours $(n=5 ; p=0.004$, paired $t$ test). For the 20 crypt cell populations examined, the u-PA content of supernatants after 24 hours' culture was $2 \cdot 14(0 \cdot 40) \mathrm{ng} / \mathrm{mg}$, which was greater than that seen in autologous cell homogenates $(0.67$ $(0.13) \mathrm{ng} / \mathrm{mg} ; p=0.001$; paired $t$ test). No differences in results were observed between colonic crypt cells from normal large bowel and from cancer bearing colons (Fig 2). No statistically significant differences were found across large bowel regions in secreted or cell associated u-PA levels (data not shown).

To determine whether u-PA secretion was being stimulated by components of the serum, crypts were cultured under serum free conditions (in which the cells have been shown to remain viable on multiple criteria ${ }^{18}$ ) and the u-PA contents of supernatants were compared with those of autologous cells cultured with $20 \% \mathrm{Nu}$-serum. As shown in Figure 3, u-PA secretion continued even in the absence of serum and the values were not significantly different.

SECRETION OF PAI-1 BY COLONIC CRYPT POPULATIONS

A time dependent increase of PAI-1 in crypt cell supernatants was also observed but the 

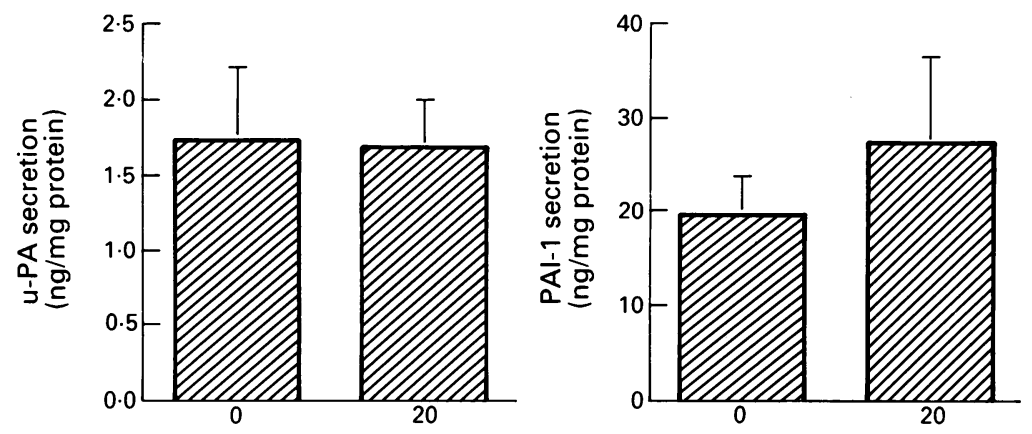

Figure 3: A comparison of the content of urokinase type plasminogen activator (u-PA) (left) and plasminogen activator inhibitor-1 (PAI-1) (right) in supernatants of colonic crypt cells when cultured for 24 hours in the presence or absence of Nu-serum at a concentration of $20 \%$ volvvol. Results are expressed as mean (SEM). The differences were not statistically significant.
Nu-serum concentration (\%)

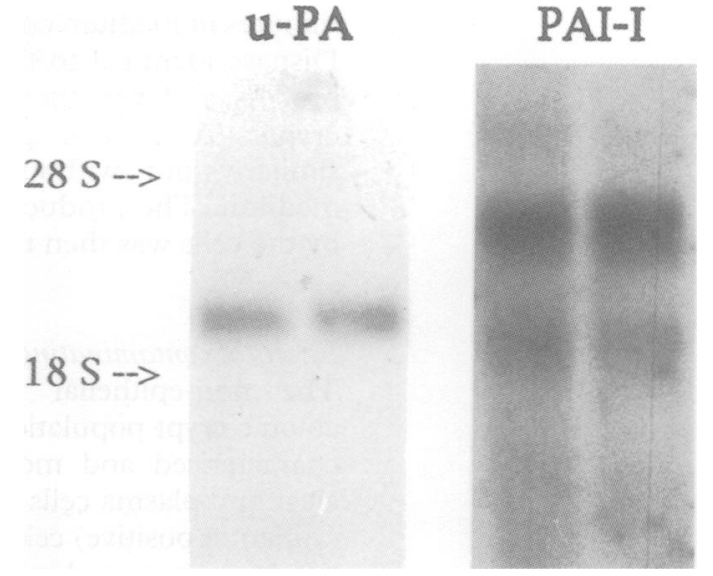

Figure 5: Northern blot analyses of $m R N A$ for urokinase type plasminogen activator $(u-P A)$ and plasminogen activator inhibitor-1 (PAI-1) in RNA prepared from a single population of colonic crypt cells after 18 hours' culture in vitro and run in duplicate. The position of ribosomal RNA bands are shown. The sizes of the transcripts are $2 \cdot 5 k b$ for $u-P A$ and 3.0 and $2 \cdot 2 k b$ for PAI-1.

present in excess of inhibitors such as PAI-1. In 15 cell populations (eight normal and seven cancer), activity in the supernatant $(7 \cdot 5(1 \cdot 8)$ $\mathrm{IU} / \mathrm{g})$ tended to be greater than that in cell homogenates $(4.8(1 \cdot 2) \mathrm{IU} / \mathrm{g} ; p=0.063$; paired $t$ test). On linear regression analysis, secreted $\mathrm{u}-\mathrm{PA}$ activity did not correlate with u-PA content $(r=0.32 ; p=0.17 ;$ Fig 4$), \quad P I-1$ content $(\mathrm{r}=-0.31)$, or u-PA:PAI-1 $(\mathrm{r}=0.02)$. Similarly, cell associated u-PA activity did not correlate with cell associated $\mathrm{u}-\mathrm{PA}$ content $(\mathrm{r}=0.32)$, PAI-1 content $(\mathrm{r}=-0 \cdot 10)$, or u-PA:PAI-1 $(r=0 \cdot 06)$.

\section{POPULATIONS}

UROKINASE ACTIVITY IN COLONIC CRYPT

To determine the relative amounts of u-PA and inhibitors present in supernatants and cell homogenates, u-PA activities after culture in serum free conditions were measured in a colorimetric assay specific for u-PA. u-PA activity was detected in all supernatants and cell homogenates tested, indicating that it was

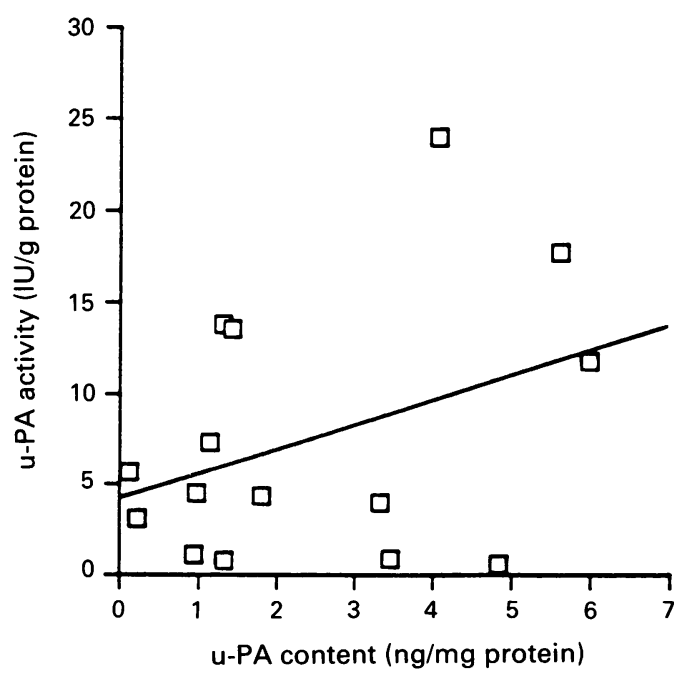

Figure 4: Linear regression analysis comparing the urokinase type plasminogen activator $(u-P A)$ content and $u-P A$ activity found in supernatants of colonic crypt cells cultured for 24 hours in serum free medium. The Pearson correlation coefficient was $0 \cdot 32$, which was not statistically significant $(p=0 \cdot 17)$.
ANALYSIS OF MRNA FOR U-PA AND PAI-1

Northern blot analysis of RNA extracted from colonic crypts cells immediately after their

$0 \quad 4 h$

u-PA

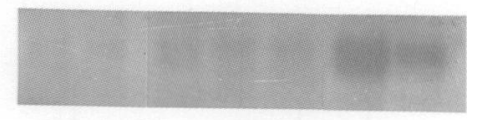

PAI-1

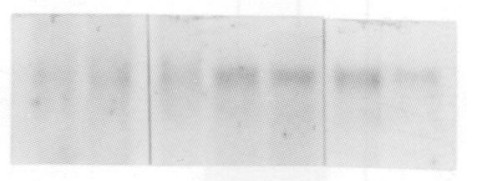

\section{GAPDH}

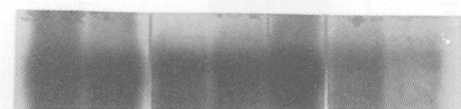

Figure 6: Northern blot analyses of $m R N A$ for urokinase type plasminogen activator $(u-P A)$, plasminogen activator inhibitor-1 (PAI-1), and glyceraldehyde phosphate dehydrogenase (GAPDH) in RNA prepared from a single population of freshly isolated colonic crypt cells (run in duplicate) and that from the autologous cells after four (in triplicate) and 18 hours' culture (in duplicate) in vitro. On densitometry, the intensity of $u-P A$ bands relative to those of GAPDH approximately doubled by four hours and had increased to 12 fold those from freshly isolated cells by 18 hours. The intensity of PAI-1 bands increased by $30 \%$ at four hours and to $100 \%$ of those of freshly isolated cells at 18 hours. 
The effect of 90 minutes' collagenase and Dispase digestion on the urokinase type plasminogen activator $(u-P A)$ and plasminogen activator inhibitor 1 (PAI-1) values in supernatants and cell homogenates of LIM1863 cells.

\begin{tabular}{lll}
\hline & Control & $\begin{array}{l}\text { Collagenase/ } \\
\text { Dispase treated }\end{array}$ \\
\hline u-PA: & $1 \cdot 98^{\star}$ & $1 \cdot 21$ \\
$\quad$ Supernatant & 0.42 & $0 \cdot 27$ \\
Cell associated & 8.62 & 6.67 \\
PAI-1 & $2 \cdot 45$ & $1 \cdot 31$ \\
Supernatant & Cell associated & \\
\hline
\end{tabular}

${ }^{\star}$ Mean of two experiments; $\mathrm{ng} / \mathrm{mg}$ protein.

isolation or after four or 18 hours' culture was performed with probes specific for the mRNA of $\mathrm{u}-\mathrm{PA}$ and PAI-1. As shown in Figure 5, both species of mRNA were detected and their sizes were similar to those published for other cell types. The effect of culture on the relative proportion of transcripts present are shown in Figure 6. Densitometry showed the band for u-PA to have $45 \%$ (mean of two experiments) of the intensity of that for GAPDH intensity in RNA extracted from freshly isolated cells. After four hours in culture, the intensity (expressed relative to that for GAPDH) of the mRNA for u-PA increased by 100 and $300 \%$ and, after 18 hours it was approximately 12 fold that in RNA from freshly isolated cells. Transcripts for PAI-1 from freshly isolated cells showed an average of three times the intensity of mRNA for GAPDH and increased by 30 and $80 \%$ after four hours' culture and by approximately 100 and $200 \%$ following 18 hours' culture in autologous cells.

\section{CONTROL EXPERIMENTS}

The effect of the collagenase/Dispase digestion was examined in LIM1863 cells by processing them identically to colonic mucosa and comparing their output and cell associated content of u-PA and PAI-1 with that of cells not so treated. The results from two experiments are shown in the Table. Enzyme treatment led to a modest diminution of both secreted and cell associated u-PA and PAI-1 levels, indicating that the isolation procedure was unlikely to be inducing the secretion of u-PA and PAI-1 by colonic crypts.

The contribution made by the non-epithelial minority population contaminating the colonic crypt preparation to the secreted u-PA value was investigated. Isolated lamina propria cells were produced by first stripping the mucosa of epithelium using EDTA and then processing the remaining lamina propria as for the crypt isolation. The resulting populations were contaminated with $<10 \%$ epithelial cells as assessed by morphology. In four experiments, the lamina propria cell associated content of u-PA $(0.47(0.20) \mathrm{ng} / \mathrm{mg})$ and the amount secreted into the supernatants $(1.02(0.20)$ $\mathrm{ng} / \mathrm{mg}$ ) was less than that of autologous colonic crypts $(1.48(0.80) \mathrm{ng} / \mathrm{mg}$ and 4.40 $(2 \cdot 04) \mathrm{ng} / \mathrm{mg}$ respectively). In three cell populations, the PAI- 1 content of the lamina propria cell homogenates $(2.92(1.30) \mathrm{ng} / \mathrm{mg})$ and culture supernatants $(5 \cdot 28(2.45) \mathrm{ng} / \mathrm{mg})$ were also measured and were also less than levels found in association with enriched colonic crypts (see above). These results indicate that the observations made with colonic crypt populations almost certainly reflected the behaviour of the majority cell population, the colonic epithelial cells.

\section{Discussion}

This study has shown that enriched isolated human colonic crypt cell populations from both normal and cancer bearing large bowel produce and secrete antigenically recognisable and enzymatically active u-PA. They also contain mRNA identified by a specific cDNA probe for u-PA. The u-PA found in the supernatants was not due solely to release of previously synthesised cellular u-PA or to lysis of the cells, since cell associated levels were about one third of those in the supernatant and colonic crypt cell populations remain viable over the culture period under the conditions used. ${ }^{16-18}$ u-PA secretion from cells was similar whether serum-free or serum-containing media was used. Of the u-PA produced by cultured crypt cells, little would have been contributed by the contaminating non-epithelial cells since they comprised a minority population in the isolated crypts and, more importantly, u-PA production from cultured lamina propria cells was $75 \%$ less (relative to cellular protein) than that for the autologous whole population. Furthermore, control experiments using LIM 1863 cells showed that the isolation process was unlikely to be a stimulus to u-PA secretion but rather tended to suppress its secretion. These data indicate, therefore, that colonic epithelial cells themselves actively produce and secrete u-PA in vitro.

Parallel studies examining the appearance of one of the specific inhibitors of u-PA in supernatants of cultured crypt cells also showed constitutive secretion of PAI-1 by cells obtained from normal or cancer bearing colons. mRNA for PAI-1 was identified in RNA preparations from colonic crypts. As observed for u-PA, PAI-1 levels that were associated with crypt cell homogenates were, on average, about one half of those in autologous supernatants after culture. Concomitant production of UPA and PAI- 1 by the same cell population has been documented for other types of epithelial cells such as keratinocytes and bronchial and alveolar epithelium. ${ }^{27-29}$ Under the in vitro conditions used in the present study, the finding of net u-PA activity in cell supernatants indicates that, in a functional sense, u-PA is being secreted in excess of its inhibitors. The poor correlation of $u-P A$, PAI-1, and u-PA:PAI-1 ratios with net u-PA activity suggests that PAI-1 is not the only inhibitor secreted by colonic epithelium.

Whether constitutive secretion of $\mathrm{u}-\mathrm{PA}$ and PAI-1 actually occurs in vivo remains uncertain since in situ methods that aim to detect proteins or mRNA suffer from poor sensitivity and, possibly, from technical problems such as the loss of u-PA during tissue preparation or poor affinity of antibodies to receptor bound 
u-PA. These problems are exemplified by the failure to demonstrate u-PA or PAI-1 associated with normal colonic epithelium by immunohistochemistry. ${ }^{30-35}$ Similarly, in situ hybridisation experiments using human colonic tissue sections have not convincingly shown mRNA for u-PA in normal colonic epithelial cells. ${ }^{9}$ The present study has demonstrated that the accumulation of u-PA in supernatants accelerates after the first six hours of culture. This observation was consistent with the appreciable increase in expression of mRNA for $\mathrm{u}-\mathrm{PA}$ relative to the total RNA in cells during culture. The mechanism underlying this induction of u-PA production is not clear. External soluble stimuli cannot be implicated since secretion of u-PA occurs in the absence of any such factors (that is, when cultured in medium containing buffers, nutrients, and antibiotics alone). The extraction process itself may be the trigger but experiments with LIM1863 cells did not show enzyme-induced u-PA secretion. The disruption of normal cell-substratum interaction or the relatively adverse nature of the in vitro conditions may themselves result in induction or acceleration of u-PA transcription. Alternatively, the removal of the cells from the influence of an in vivo suppressive factor(s) or the production in vitro of a stimulus from the cells themselves may be playing a role. The nature of any such factors requires elucidation.

u-PA may have particular relevance to the biology of colonic epithelium. Important components of its basement membrane (such as laminin, proteoglycan, and fibronectin) are known to be able to be digested by plasmin and by $u-P A$. The production of not only u-PA but also at least one of its specific inhibitors by colonic epithelium indicates that the epithelial cells have a potential in-built mechanism by which net u-PA activity on the cell surface can be modulated. Studies of promyeloid, fibroblastic, and sarcomatous cells and a malignant cell line of epithelial origin have found that u-PA receptors are localised at sites of cell-cell and cell-substratum contacts, whereas PAI-1 is diffusely distributed on the plasma membrane. ${ }^{36-38}$ Membrane associated u-PA activity seems to play a critical role in cell motility of a number of motile cell types such as normal keratinocytes, fibroblasts, and monocytes, ${ }^{4}$ or in tissue invasion of cancer cells. ${ }^{27}$ Cell motility and tightness of cell-cell interactions are important in colonic epithelia. Changes in the activity of receptor bound u-PA might affect biological aspects that depend upon the strength of cell-cell and cellsubstratum contacts since they are intimately associated with protease sensitive molecules such as cadherins, laminin, and fibronectin. Loosening of these contacts might result in, for example, increased paracellular permeability, a change in the migration of cells from the base of the crypt to the surface, and increased loss of cells into the lumen. In colitis, paracellular permeation of luminal macromolecules through the epithelium into the lamina propria is increased, ${ }^{39}$ cell turnover is raised, ${ }^{40}$ and ulceration is characteristic; because mucosal
u-PA content and activity are increased, 67 u-PA may be responsible.

In conclusion, this study shows that human colonic epithelial cells freshly isolated from macroscopically normal large bowel secrete both u-PA and PAI-1. The presence of net u-PA activity in both supernatants and cell homogenates indicates that under the in vitro culture conditions used, u-PA secretion may be greater than that of its inhibitors. In view of the current understanding of the biology of the u-PA system, these findings support the hypothesis that $\mathrm{u}-\mathrm{PA}$ plays an important role in the normal physiology of colonic epithelium and in the pathophysiology of inflammatory and neoplastic diseases of the large bowel.

This work was supported in part by a grant from the National Health and Medical Research Council of Australia. The authors thank Mr J C B Penfold, Mr I T Jones, and other surgeons of The Royal Melbourne Hospital for the supply of fresh colonic tissue and the pathologists of the Department of Anatomical Pathology for promptly processing resected bowel. The human u-PA cDNA contained in pcUK176 was a gift of Dr R Miskin Human PAI-1 cDNA in pGEM ${ }_{3}$ and human u-PAR CDNA in Bluescript MB + were gifts of Dr D J Loskutoff.

Previously published in part in abstract form in Gastroenterology 1992; 102: A357.

1 Gold LI, Schwimmer R, Quigley JP. Human plasma fibronectin as a substrate for human urokinase. Biochem $f$ 1989; 262: 529-34.

2 Stephens RW, Pollanen J, Tapiovaara H, Leung K-C, Sim PS, Salonen EM, et al. Activation of pro-urokinase and plasminogen on human sarcoma cells: a proteolytic system with surface-bound reactants. $₹$ Cell Biol 1989; system with surf.

3 Hollas W, Boyd D. Urokinase-dependent proteolysis in cultured cancer is directed by its receptor. Semin Thromb Hemost 1991; 17: 225-30.

4 Kirchheimer JC, Binder BR. Function of receptor-bound urokinase. Semin Thromb Hemost 1991; 17: 246-50.

5 Blasi F. Surface receptors for urokinase plasminogen activator. Fibrinolysis 1988; 2: 73-84.

6 Elliott R, Stephens RW, Doe WF. Expression of urokinasetype plasminogen activator in the mucosal lesions of inflammatory bowel disease. $\mathcal{F}$ Gastroenterol Hepatol 1987; 2: 517-23.

7 De Bruin PAF, Crama-Bohbouth G, Verspaget HW, et al. Plasminogen activators in the intestine of patients with inflammatory bowel disease. Thromb Haemost 1988; 60: 262-6.

8 Gibson PR, van de Pol E, Doe WF. Cell associated urokinase activity and colonic epithelial cells in health and disease. Gut 1991; 32: 191-5.

9 Pyke C, Kristensen P, Ralfkiaer E, Grondahl-Hansen J, Eriksen J, Blasi F, Dano K. Urokinase-type plasminogen activator is expressed in stromal cells and its receptor in cancer cells at invasive foci in human colon adenocarcinomas. Am f Pathol 1991; 138: 1059-67.

10 Kristensen P, Eriksen J, Dano K. Localization of urokinasetype plasminogen activator messenger RNA in the normal mouse by in situ hybridization. $f$ Histochem Cytochem 1991; 39: 341-9.

11 Boyd D, Florent G, Kim P, Brattain M. Determination of the levels of urokinase and its receptor in human colon carcinoma cell lines. Cancer Res 1988; 48: 3112-6.

12 Hart D, Rehemtulla A. Plasminogen activators and their nhibitors: regulators of extracellular proteolysis and cell function. Comp Biochem Physiol 1988; 90B: 691-708.

13 Sprengers ED, Klut C. Plasminogen activators inhibitors Blood 1987; 69: 381-7.

14 Suzuki K, Deyashiki Y, Nishioka J, Toma K. Protein C inhibitor: structure and function. Thromb Haemost 1989, 61: 337-42.

15 Baker JB, Grouke RS. Protease nexins and cellular regulation. Semin Thromb Hemost 1986; 12: 216-20.

16 Gibson PR, van de Pol E, Maxwell LE, Gabriel A, Doe WF. Isolation of colonic crypts that maintain structural and metabolic viability in vitro. Gastroenterology 1989; 96: 283-91.

17 Gibson PR, Moeller I, Kagelari O, Folino M, Young GP Contrasting effects of butyrate on expression of phenotypic markers of differentiation in neoplastic and nontypic markers of differentiation in neoplastic and nonneoplastic colonic epithelial

18 Gibson PR, Rosella O, Young GP. Serum-free medium increases expression of markers of differentiation in human colonic crypt cells. Gut (in press)

19 Bradford M. A rapid and sensitive method for the quantitation of microgram quantities of protein utilizing the principle of protein dye binding. Anal Biochem 1976; 72 248-54. 
20 Janicke F, Schmitt M, Hafter R, Hollrieder A, Babic R, Ulm $\mathrm{K}$, et al. Urokinase-type plasminogen activator (u-PA) antigen is a predictor of early relapse in breast cancer. Fibrinolysis 1990; 4: 69-78.

21 Coleman PL, Green GDJ. A sensitive coupled assay for plasminogen activator using a thiol ester substrate for plasminogen activator using a thiol ester subs

22 Declerck PJ, Alessi MC, Verstreken M, Kruithof EKO, Juhan-Vague I, Collen D, et al. Measurement of plasminogen activator inhibitor (PAI-1) in biological fluids, minogen activator inhibitor (PAI-1) in biological fluids,
with a murine monoclonal antibody based enzyme-linked immunoabsorbent assay. Blood 1988; 71: 220-5.

23 Chomczynski P, Sacchi N. Single step method of RNA isolation by acid guanidium thiocyanate-phenolchloroform extraction. Anal Biochem 1987; 162: 156-9.

24 Novak U, Cocks BG, Hamilton JA. A labile repressor acts through the NFkB-like binding sites of the human urokinase gene. Nuc Acids Res 1991; 19: 3389-93.

25 Ny T, Sawdey M, Lawrence D, Millan JL, Loskutoff DJ. Cloning and sequence of a cDNA coding for the human $\beta$-migrating endothelial-cell-type plasminogen activator inhibitor. Proc Natl Acad Sci USA 1986; 83: 6776-80.

26 Whitehead RH, Jones JK, Gabriel A, Lukies RE. A new colon carcinoma cell line (LIM1863) that grows as organoids with spontaneous differentiation into crypt-like structures in vitro. Cancer Res 1987; 47: 2683-9.

27 Lazarus GS, Jensen PJ. Plasminogen activators in epithelial biology. Sem Thromb Hemost 1991; 17: 210-6.

28 Gerwin BI, Keski-Oja J, Seddon M, Lechner JF, Harris CC. TGF-beta modulation of urokinase and PAI-1 expression in human bronchial epithelial cells. Am f Physiol 1990; 259: L 262-9.

29 Gross TJ, Simon RH, Kelly CJ, Sitrin RG. Rat alveolar epithelial cells concomitantly express plasminogen activator inhibitor-1 and urokinase. Am F Physiol 1991; 260: L286-95.

30 Kohga S, Harvey SR, Weaver RM, Markus G. Localization of plasminogen activators in human colon cancer by immunoperoxidase staining. Cancer Res 1985; 45: 1787-96.
31 Grondahl-Hansen J, Ralfkiaer E, Kirkeby LT, Kristensen P, Lund LR, Dano K. Localization of urokinase-type plasminogen activator in stromal cells in adenocarcinomas of the colon in humans. Am f Pathol 1991; 138: 111-7.

32 Sier CF, Fellbaum C, Verspaget HW, Schmitt M, Griffioen $\mathrm{G}$, Graeff $\mathrm{H}$, et al. Immunolocalization of urokinase-type colorectum. Histopathology 1991; 19: 231-7.

33 Tanaka N, Fukao H, Ueshima S, Okada K, Yasutomi $M$, Matsuo O. Plasminogen activator inhibitor 1 in human carcinoma tissues. Int $f$ Cancer 1991; 48: 481-4.

34 Buo $L$ Lyberg T, Jorgensen HT, Aasen AO. Location of plasminogen activator (PA) and PA inhibitor in of plasminogen activator (PA) and PA inhibitor in human

35 Koretz K, Moller P, Schwartz-Albiez R. Plasminogen activators and plasminogen activator inhibitors in human colorectal carcinoma tissues are not expressed by the tumour cells. Eur $\mathcal{F}$ Cancer 1993; 29A: 1184-9.

36 Pollanen J, Saksela O, Salonen EM, Andreasen P, Nielsen L, Dano K, Vaheri A. Distinct localizations of urokinasetype plasminogen activator and its type I inhibitor under cultured human fibroblasts and sarcoma cells. $7 \mathrm{Cell}$ Biol 1987; 104: 1085-96.

37 Takahashi $K$, Ikeo $K$, Gojorbori $T$ Tanifuji $M$. Local function of urokinase receptor at the adhesion contact function of urokinase receptor at the adhesion contact (suppl): 55-61.

38 Schmitt M, Chucholowski N, Busch E, Hellman D, Wagner B, Goretzki L, et al. Fluorescent probes as tools to assess the receptor for the urokinase-type plasminogen activator on tumor cells. Sem Thromb Hemost 1991; 17: 291-302.

39 O'Morain CO, Abelow AC, Chervu LR, Fleischner GM, Das KM. Chromium 51-ethylenediaminetetraacetate test: a useful test in the assessment of inflammatory bowel disease. F Lab Clin Med 1986; 108: 430-5.

40 Allan A, Bristol JB, Williamson RCN. Crypt cell production rate in ulcerative proctocolitis: differential increments in remission and relapse. Gut 1985; 26: 999-1003. 